\title{
Perancangan Mesin Pembuat Serundeng Kapasitas 10 Kg Menggunakan Metode Pahl \& Beitz
}

\author{
Muhammad Naufal Al Ghani' ${ }^{1}$, Aris Suryadi ${ }^{2}$ \\ ${ }^{1} J u r u s a n$ Teknik Mesin, Politeknik Negeri Bandung, Bandung 40012 \\ E-mail : muhammad.naufal.tpkm17@polban.ac.id \\ ${ }^{2}$ Jurusan Teknik Mesin, Politeknik Negeri Bandung, Bandung 40012 \\ E-mail : aris_aers@yahoo.com
}

\begin{abstract}
ABSTRAK
Pembuatan serundeng kelapa indung melewati 2 tahapan proses, yaitu proses pengukusan dan proses pengeringan. Proses pengukusan membutuhkan waktu 30 menit sedangkan proses pengeringan membutuhkan 300 menit dan selama proses pengeringan serudeng harus diaduk. Saat ini proses pembuatan serundeng kelapa indung masih menggunakan cara konvensional atau manual sehingga membutuhkan waktu dan tenaga manusia yang banyak. Oleh karena itu dibutuhkan perancangan mesin pembuat serundeng kelapa indung yang berguna untuk mengurangi tenaga manusia pada saat proses pembuatan. Proses perancangan menggunakan metode yang di ambil dari buku perancangan Pahl \& Beitz. . Dalam merancang mesin ini, terdapat 3 tahapan secara garis besar, yaitu :tahap merencana untuk mengetahui secara detail tentang kebutuhan dan kondisi di lapangan, tahap mengonsep untuk menentukan konsep terbaik, tahap merancang detail dengan melakukan perhitungan, pembuatan $3 \mathrm{~d}$ model, dan Perhitungan harga produksi pokok mesin. Luaran penelitian ini di dapat rancangan mesin yang menggabungkan 2 proses menjadi satu yaitu proses pengukusan dan proses pengeringan yang di sertai pengaduk dengan kapasitas per proses $10 \mathrm{~kg}$, daya motor 40 watt dan dimensi mesin $854 \mathrm{~mm}$ x $480 \mathrm{~mm}$ x $1362 \mathrm{~mm}$, putaran pada pengaduk sebesar $14 \mathrm{RPM}$, rasio gearbox 1:100 dan berat $76 \mathrm{~kg}$. Mesin berjalan secara otomatis menggunakan kontrol Arduino.
\end{abstract}

Kata Kunci

Perancangan, Serundeng, pengukusan, pahl \& Beitz.

\section{PENDAHULUAN}

Kelapa merupakan salah satu tumbuhan yang dapat ditemukan di daerah tropis, terutama di daerah yang mempunyai suhu lingkungan yang tinggi. Di Indonesia khususnya di Jawa Barat, pohon kelapa banyak tumbuh di bagian selatan Jawa Barat. Pohon kelapa bagi warga setempat dapat menjadi sumber penghasilan. Karena mulai dari daun, batang hingga akar pohon kelapa dapat digunakan dalam kehidupan sehari hari.

Salah satu olahan kelapa, yaitu serundeng yang pengirimannya sampai keluar negeri adalah olahan serundeng yang diproduksi oleh UMKM Kelapa Indung. Pada UMKM Kelapa Indung serundeng masih dibuat dengan menggunakan metode konvensional yang dapat memakan waktu hingga 5-7 jam untuk sekali proses pembuatan hingga siap untuk di kemas, selain itu untuk sekali produksi membutuhkan 2-3 tenaga kerja.

Proses pembuatan serundeng dimulai dari tahap persiapan, yaitu mempersiapkan alat yang akan digunakan dalam proses pembuatan serundeng, seperti timbangan, wajan, kompor, alat kukusan, pengaduk kayu, pisau, wadah kelapa parut, talenan dan lain-lain. selain itu diperlukan untuk menyiakan bahan yang akan digunakan. Tahapan ini memerlukan waktu sekitar 30 menit. Proses pengukusan berguna untuk mengurangi kadar air dalam kelapa parut tanpa adanya pengurangan nutrisi yang berlebih, penggunaan pengukusan dapat mengurangi pengurangan nutrisi yang terjadi akibat penggorengan sebanyak $11,85 \%$. [1] Setelah proses persiapan selesai, selanjutnya adalah tahap pelaksanaan atau pembuatan yang dimulai dengan pengukusan kelapa parut yang sudah disiapkan menggunakan kompor. Proses ini memerlukan waktu 30 menit. Setelah proses pengukusan selesai, kelapa parut di masukan ke dalam wajan yang sudah dipanaskan lalu disangrai di atas api sedang dan diaduk secara teratur agar kelapa parut tidak gosong. Selagi diaduk, ditambahkan bumbu-bumbu yang sudah disiapkan secara bertahap. Proses ini memerlukan waktu 5 hingga 6 jam.

Total waktu proses produksi dapat mencapai waktu 7 jam dengan 2 sampai 3 tenaga kerja manusia. Untuk sekali produksi, UMKM Kelapa indung dapat menghasilkan 3,5-4 kg serundeng dari $5 \mathrm{~kg}$ bahan baku kelapa parut. Hal itu dikarenakan terdapat pengupan air dan kelapa parut yang menjadi kerak karena kurang ratanya pada saat proses pengadukan. Proses produksi tersebut tidak efektif karena terdapat $10-20 \%$ kelapa yang gosong dan dari segi biaya membutuhkan biaya lebih untuk meningkatkan proses produksi yang mana akan menambah tenaga kerja.

Gambaran produksi hasil observasi menggambarkan masalah yang terjadi pada proses produksi serundeng pada UMKM kelapa indung, yakni masih menggunakan cara tradisional untuk membuat serundeng sehingga proses produksi tidak efektif dari segi tenaga kerja. 


\section{METODOLOGI}

Tujuan dari dilakukannya penelitian ini adalah membuat rancangan mesin pembuat serundeng yang menggabungkan dua proses menjadi satu, yaitu proses pengukusan dan proses pengeringan dengan kapasitas $10 \mathrm{~kg}$ per proses. Ruang lingkup penelitian ini yaitu menentukan daftar tuntutan, konsep terpilih, melakukan perhitungan detail dan pembuatan model $3 \mathrm{~d}$. Metodologi yang digunakan mengikuti metode yang terdapat pada buku Engineering Design [2].berikut merupakan diagram metode penelitian yang akan digunakan.

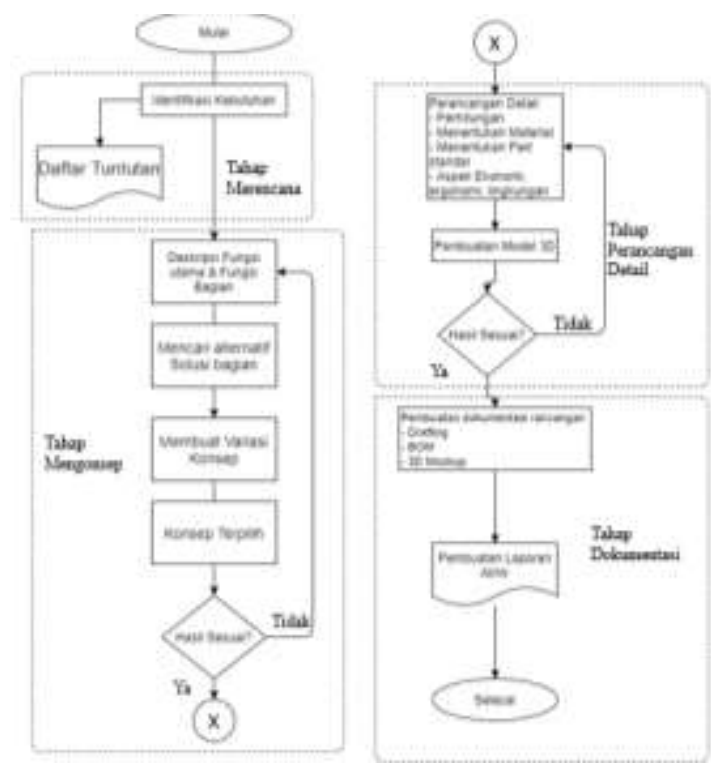

Gambar 1. Metodologi Perancangan

\subsection{Tahap Perencanaan}

Pada tahap ini melakukan identifikasi masalah. Beberapa hal yang dibahas yaitu menjelaskan fungsi dan cara mesin penbuat serundeng secara umum, kajian mesin pembuat serundeng yang ada di pasaran, mencari keinginan konsumen dan pasar dengan luaran daftar tuntutan.

\subsection{Tahap Perancangan Konsep}

Pada tahap ini dimulai dengan menentukan fungsi utama pada mesin pembuat serundeng dan fungsi bagian yang akan diuraikan untuk mendapatkan alternatif solusi bagian yang nantinya akan dibuat variasi konsep mesin pembuat serundeng. Variasi konsep rancangan yang telah dibuat dinilai dengan kriteria manufaktur dan pengguna untuk mendapatkan konsep terbaik

\subsection{Tahap Perancangan Detail}

Tahap perancangan detail merupakan uraian dari konsep yang sudah terpilih, pada tahap ini akan dilakukan perhitungan, analisis aspek ekonomi, dan pembuatan $3 \mathrm{~d}$ model sebagai hasil akhir.

\subsection{Tahap Dokumentasi}

Tahap dokumentasi merupakan tahap pembuatan dokumentasi dari rancangan mesin pembuat serundeng yang sudah dibuat berupa, cara pengoprasian alat dan spesifikasi akhir alat yang dirancang.

\section{HASIL DAN PROSES}

\subsection{Identifikasi Penelitian}

Proses identifikasi masalah yang dilakukan pada penelitian kali ini menggunakan kajian kebutuhan pengguna melalui wawancara dengan narasumber, yaitu pemilik UMKM Kelapa indung. dari hasil wawancara dengan pemilik UMKM kelapa indung, didapat permasalahan yang terdapat pada UMKM kelapa indung yaitu:

a. Pembuatan serundeng yang memerlukan banyak tenaga manusia

b. Proses pengadukan yang tidak sempurna mengakibatkan kerak pada dasar panci dan mengurangi volume serundeng yang jadi.

c. Proses pemindahan kelapa parut dari proses pengukusan ke proses pengeringan beresiko terjadinya kecelakaan kerja.

Selain itu dilakukan Customer Window yang digunakan untuk menggambarkan kinerja mesin atau metode yang saat ini digunakan dalam bentuk keinginan, kekurangan dan kepuasan sehingga dapat menentukan kebijakan, yakni yang dipertahankan, yang dihilangkan, diabaikan dan di kembangkan. Gambaran dari Customer Window dapat dilihat pada Gambar 2.

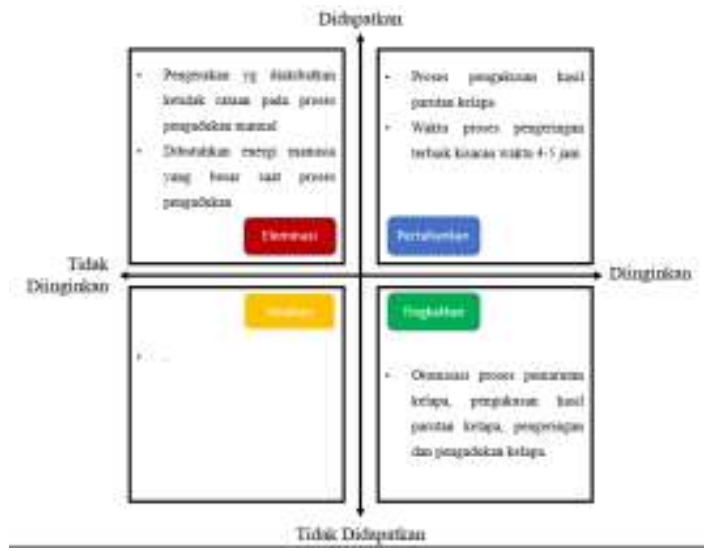

Gambar 2. Customer Windows

Dari hasil identifikasi yang sudah dilakukan, didapat daftar tuntutan yang akan menjadi acuan dalam merancang mesin pembuat serundeng di UMKM kelapa indung, sebagai berikut :

a. Kapasitas produksi sebesar $10 \mathrm{~kg} /$ proses

b. Mesin yang dirancang dapat membantu proses [3] indung yakni pada tahap pengukusan dan pengeringan 
c. Mesin tidak mengeluarkan suara bising

d. pemanas dapat menggunakan gas LPG (liquefied petroleum gas) dan kayu bakar

e. bahan yang bersentuhan dengan produk menggunakan bahan food grade

f. waktu produksi produk 335 menit

g. perawatan mudah.

\subsection{Perancangan Konsep}

Hal pertama yang dilakukan dalam perancangan konsep yaitu pembuatan black box untuk menentukan fungsi utama dan menjabarkan fungsi bagian. black box dari fungsi secara keseluruhan dapat dilihat pada Gambar 3.

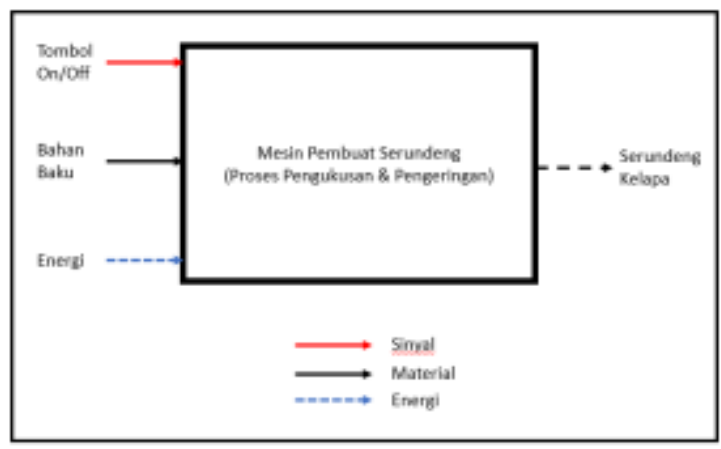

Gambar 3. Black Box Fungsi Keseluruhan

Fungsi bagian dijabarkan dalam morfologi sehingga menghasilkan 6 fungsi bagian. Dari masing-masing fungsi bagian tersebut, dibuat 3 sketsa yang nantinya akan dinilai dengan dua kriteria, yaitu kriteria manufaktur dan user criteria. Dari hasil penilaian tersebut variasi konsep 1 mendapatkan nilai tertinggi. Variasi Konsep 1 dapat dilihat pada Gambar 4.

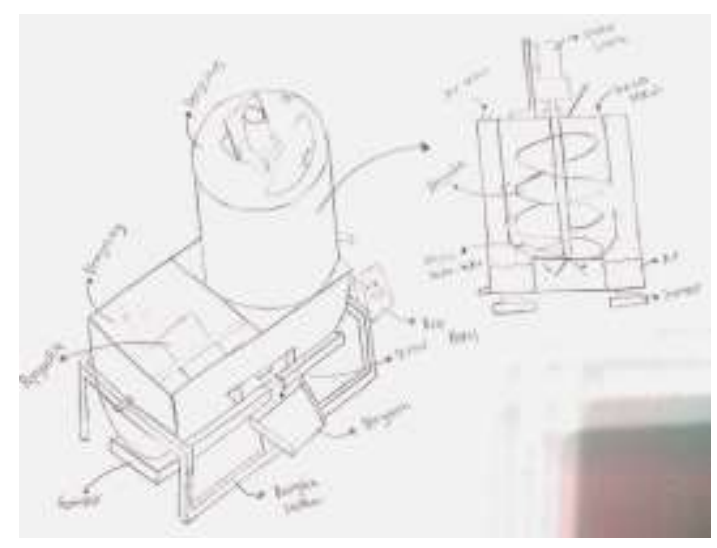

Gambar 4. Konsep Terpilih

Variasi konsep 1 menggunakan kompor yang biasa digunakan dalam roasting kopi dengan sumber energi gas LPG. Pengadukan menggunakan 4 bilah. Rangka menggunakan besi hollow. Sumber energi untuk pemutaran pengaduk menggunakan motor listrik ac yang Bersatu dengan gearbox. Pengukusan menggunakan model vertikal. Variasi konsep ini menggunakan kontrol Arduino.
Gambar rancangan tersebut masih berupa gambaran secara kasar yang dimana masih dapat berubah pada saat proses perancangan detail.

\subsection{Perancangan Detail}

\subsubsection{Sistematika Perhitungan}

Sistematika perhitungan dibuat untuk mempermudah perancangan pada tahapan perhitungan. Sistematika perhitungan yang akan dilakukan dapat dilihat pada Gambar 5.
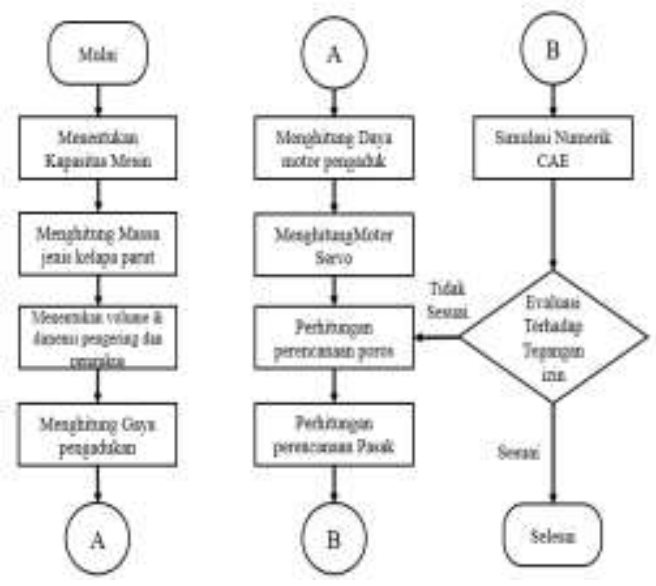

Gambar 5. Sistematika Perhitungan

\subsubsection{Perhitungan Volume dan Dimensi Mesin}

Kapasitas pada mesin pembuat serundeng ini sudah ditentukan berdasarkan daftar tuntutan yang telah didapat, yaitu $10 \mathrm{~kg}$ per proses. Untuk menentukan dimensi dari wadah pengukusan dan wadah pengeringan, diperlukan massa jenis $\left(\mathrm{Kg} / \mathrm{m}^{3}\right)$ kelapa parut. Maka dari itu dilakukan percobaan dengan membeli 250 gr kelapa parut untuk mengetahui massa jenis $\left(\mathrm{Kg} / \mathrm{m}^{3}\right)$ kelapa parut tersebut.

Dari hasil percobaan 250gr kelapa parut memiliki volume sebesar $500 \mathrm{ml}$. sehingga dengan persamaan 1 yang diperoleh dari laporan tugas akhir yang ditulis oleh Muhammad Imam Adikuncoro [5]. maka didapat bahwa massa jenis kelapa $\left(\mathrm{Kg} / \mathrm{m}^{3}\right)$ parut sebesar

$$
\rho=\frac{m}{v}=\frac{0,25 \mathrm{~kg}}{0,0005}=500 \mathrm{~kg} / \mathrm{m}^{3}
$$

Keterangan :

$$
\begin{array}{ll}
\rho & =\text { Massa Jenis }\left(\mathrm{Kg} / \mathrm{m}^{3}\right) \\
m & =\operatorname{Massa}(\mathrm{Kg}) \\
v & =\operatorname{Volume}\left(\mathrm{m}^{3}\right)
\end{array}
$$

Maka untuk menampung 10kg kelapa parut dibutuhkan wadah minimal 20L

Dengan pertimbangan dalam pengukusan dibutuhkan ruang kosong untuk bergeraknya uap maka volume yang dibuat untuk ruang pengukusan sebesar 40L dan pada proses pengeringan terdapat pengadukan serta akan ditambahkan bumbu lainya, maka ditentukan untuk wadah pengeringan sebesar 60L dengan dimensi 
wadah pengukus dan wadah pengering dapat dilihat pada Gambar 6 dengan sebelah kiri merupakan wadah pengukus dan kanan wadah pengeringan.
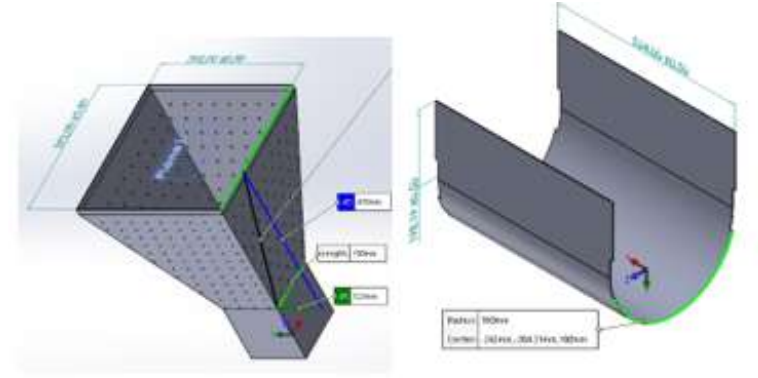

Gambar 6. Dimensi Wadah Pengukus dan Pengering

\subsubsection{Perhitungan Daya Pengadukan}

Bahan makanan yang diaduk adalah kelapa parut yang sudah ditambahkan dengan bumbu dan bahan makanan lainya dengan berat sekitar $10 \mathrm{~kg}$. pengaduk berbentuk bilah dengan jumlah bilah sebanyak 4 sehingga setiap bilah mengaduk 2,5kg bahan makanan. Bentuk pengaduk dapat dilihat pada Gambar 7.

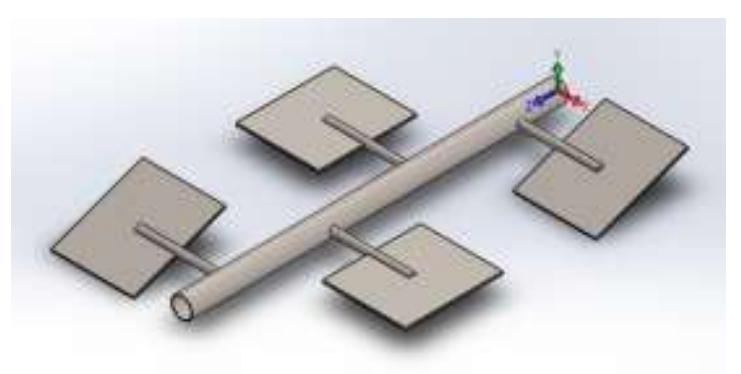

Gambar 7. Pengaduk

Untuk menentukan daya pengadukan yang diperlukan, harus menghitung terlebih dahulu torsi yang bekerja pada proses pengadukan. Metode perhitungan daya pengadukan mengacu pada laporan tugas akhir yang ditulis oleh Muhammad Imam Adikuncoro [5]. Untuk mengetahui torsi $(\mathrm{Nm})$ yang bekerja pada proses pengadukan dapat menggunakan Persamaan (2).

$$
T=F \times R \times n=\left(\frac{m}{n} \times f c \times g\right) \times R \times n
$$

Keterangan :

$\mathrm{T}$ : Torsi $(\mathrm{Nm})$

F : Gaya $(\mathrm{N})$

$\mathrm{R}$ : Jarak poros terpanjang $(\mathrm{m})$

$\mathrm{n}:$ Jumlah poros pengaduk

$\mathrm{m}:$ Massa $(\mathrm{kg})$

fc : Safety factor

$\mathrm{g}$ : Gaya gravitasi $\left(\mathrm{m} / \mathrm{s}^{2}\right)$

$$
T=\left(\frac{5 \mathrm{~kg}}{\mathrm{z}} \times 2 \times 10 \frac{\mathrm{m}}{\mathrm{s}}\right) \times 0,175 \mathrm{~m} \times 2=17,5 \mathrm{Nm}
$$

Dengan daya yang dibutuhkan dapat dihitung menggunakan persamaan (4).

$$
P=\frac{T \times 2 \pi \times n}{60}=\frac{17,5 \times 2 \pi \times 14}{60}=40,2 \mathrm{Watt}
$$

Berdasarkan perhitungan dari persamaan (4) dipilih motor gearbox dengan daya output sebesar 40 watt dan rasio gear 1:100 dengan putaran output sebesar 14rpm.

\subsubsection{Perhitungan Poros dan Pasak}

Perhitungan Poros dan pasak dilakukan secara manual untuk menentukan diameter minimal poros yang akan digunakan. Poros yang akan dihitung sendiri yaitu poros pada pengaduk dan poros untuk pintu penyangga pengukus. Kedua poros menggunakan bahan stainless steel 304 yang memiliki tegangan tarik maksimal $52 \mathrm{~kg} / \mathrm{mm}^{2}$ karena bersentuhan langsung dengan bahan makanan. Rumus yang digunakan dalam menghitung poros dan pasak menggunakan rumus yang diambil dari buku yang ditulis oleh sularso [4]. Hasil perhitungan

\begin{tabular}{|c|c|c|}
\hline No & Keterangan & Spesifikasi \\
\hline 1 & $\begin{array}{l}\text { Poros } \\
\text { Pengaduk }\end{array}$ & Diameter minimum $\emptyset 22$ \\
\hline 2 & $\begin{array}{l}\text { Poros } \\
\text { Penyangga } \\
\text { Pengukus }\end{array}$ & Diameter Minimum $\varnothing 12$ \\
\hline 3 & Pasak & $\begin{array}{l}\text { Bahan : SNC21 } \\
\text { Lebar (b) }: 7 \\
\text { Tebal (h) }: 7 \\
\text { Panjang (l) }: 24 \\
\text { Kedalaman pasak ke poros } \\
(\mathrm{t} 1): 4 \\
\text { Kedalaman pasak ke naff }: 3\end{array}$ \\
\hline
\end{tabular}
dapat dilihat pada Tabel 1.

Tabel 1. Hasil Perhitungan Tegangan

\subsubsection{Konstruksi dan Spesifikasi Mesin}

Konstruksi mesin pembuat serundeng akan diperlihatkan dengan gambar $3 \mathrm{~d}$ yang dibuat dengan bantuan aplikasi Solid Works. Hasil rancangan model 3D ada beberapa perubahan dari konsep terpilih pada tahapan konseptual, dikarenakan dari hasil perencanaan detail ada beberapa yang sebaiknya di ubah.

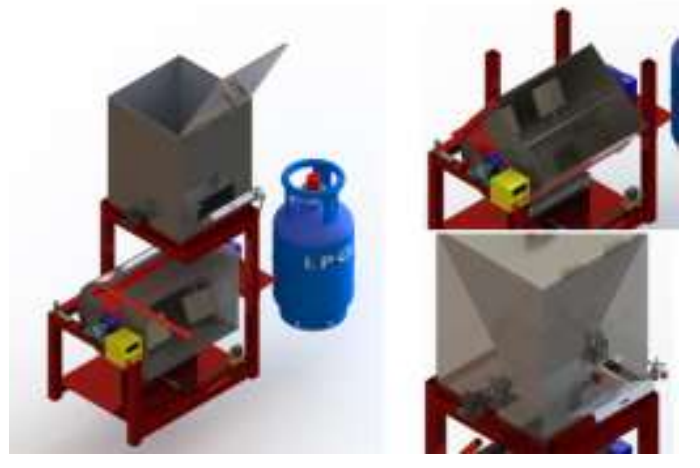

Gambar 8. Hasil Rancangan 
Detail spesifikasi dari mesin pembuat serundeng ini dapat dilihat pada Tabel 2.

Tabel 2. Spesifikasi Mesin

\begin{tabular}{cll}
\hline No. & \multicolumn{1}{c}{ Keterangan } & \multicolumn{1}{c}{ Spesifikasi Komponen } \\
\hline 1 & Fungsi & $:$ Membuat serundeng \\
2 & Kapasitas & $: \pm 10 \mathrm{~kg} /$ Proses \\
& Produksi & \\
3 & Motor Listrik & $: 40 \mathrm{Watt} 1400 \mathrm{Rpm}$ \\
4 & Gearbox & $: 1: 100$ \\
5 & Putaran Pengaduk & $: \pm 14 \mathrm{RPM}$ \\
6 & Dimensi Total & $: 854 \mathrm{x} 480 \mathrm{x} 1362 \mathrm{~mm}$ \\
7 & Berat total & $: \pm 76 \mathrm{~kg}$ (Tidak termasuk \\
& & Gas) \\
8 & Daya Total Mesin & $: \pm 100 \mathrm{Watt}$ \\
9 & Harga Produksi & $:$ Rp10.162.952,- \\
10 & Fitur Tambahan & $:$ Pengaturan Timer \\
\hline
\end{tabular}

\subsubsection{Analisis Harga Produksi Pokok Mesin}

Harga mesin dihitung berdasarkan beberapa pengeluaran, yaitu bahan pokok non standar, komponen standar, biaya pembuatan ( mesin dan operator) dan biaya assembly. Biaya pembuatan dipatok berdasarkan salah satu workshop yang berada dengan harga produksinya sekitar 40rb per jam sudah termasuk operator dan mesin. Detail harga dapat dilihat pada Tabel 3.

Tabel 3. Analisis Harga Pokok Produksi Mesin

\begin{tabular}{|c|c|}
\hline Jenis Pengeluaran & Harga \\
\hline Bahan Baku (Part Non Standar) & Rp5.778.949 \\
\hline Komponen Standar & Rp2.604.000 \\
\hline Pembuatan & Rp1.451.042 \\
\hline Assembly & Rp335.417 \\
\hline TOTAL & Rp10.168.952 \\
\hline
\end{tabular}

\subsubsection{Cara Kerja Mesin}

Mesin pembuat serundeng di UMKM kelapa indung ini bekerja secara otomatis. Langkah pertama yang dilakukan untuk membuat serundeng menggunakan mesin ini adalah

a. Mempersiapkan mesin dengan membersihkan wadah pengukus dan wadah pengering

b. Siapkan bahan-bahan yang dibutuhkan.

c. Buka tutup wadah pengukusan (atas) lalu masukan kelapa parut.

d. Nyalakan mesin. Kontrol akan menyalakan kompor pengukusan secara otomatis selama 30 menit. Setelah 30 menit kompor akan mati dengan sendirinya lalu terdapat jeda untuk menurunkan kadar air yang ada di kelapa parut selama 3 menit.

e. Setelah itu motor servo akan memutarkan pintu pengukus bagian bawah untuk memindahkan kelapa parut yang sudah di kukus masuk ke dalam wadah pengeringan. f. Setelah itu kontrol akan menyalakan motor pengaduk dan kompor pengeringan secara bersamaan. Pada proses ini kelapa parut akan di sangrai dan di aduk selama 5 jam. Selama proses pengeringan masukan bumbu yang sudah disiapkan.

g. Setelah 5 jam pengaduk kan kompor akan berhenti. Lalu kontrol akan menyalakan alarm tanda bahwa proses pengeringan sudah selesai.

h. Buka kunci pada wadah pengering agar wadah pengering dapat dimiringkan untuk mengeluarkan serundeng yang sudah jadi.

i. Masukan serundeng ke dalam kemasan.

\section{PEMBAHASAN}

Mesin hasil rancangan bekerja dengan dua tahapan utama. Tahap pertama merupakan pengukusan kelapa parut. Tahap selanjutnya yaitu pengeringan. Kedua tahap tersebut menggunakan gas LPG sebagai sumber panasnya. Hal tersebut sesuai dengan keinginan konsumen yang menginginkan gas LPG sebagai sumber panasnya. Pada tahap pengeringan terdapat pengaduk yang menggunakan motor AC 40 watt yang terhubung dengan gearbox rasio 1 : 100 dengan luaran putaran 14 prm. Bahan yang bersentuhan secara langsung dengan produk menggunakan stainless steel 304. Dengan spesifikasi yang didapat, sudah sesuai dengan daftar tuntutan.

\section{KESIMPULAN}

Mesin pembuat serundeng ini berfungsi secara otomatis yang berfungsi membantu proses pengukusan dan pengeringan dalam pembuatan serundeng di UMKM kelapa indung. Evaluasi yang telah dilakukan menunjukan bahwa rancangan mesin ini telah memenuhi daftar tuntutan dan keinginan mitra yaitu UMKM Kelapa indung. Rancangan mesin pembuat serundeng ini memiliki kelebihan yaitu mesin yang berjalan secara otomatis, konstruksi yang sederhana dan pengeluaran serundeng yang sudah jadi mudah.

\section{DAFTAR PUSTAKA}

[1] C. E. e. aL, "Analisis Perbandingan Proses Pengilahan Ikan Lele Terhadap Kadar Nutrisinya," Indonesian Journal Of Chemical Analysis, pp. Vol. 04. 40-46, 2021.

[2] P. K, B. W. G dan J. G. Feldhsun, Engineering Design, London: Springer, 2003.

[3] J. Siregar, "Rancang Bangun Mesin Pengolahan Serundeng dengan Menggunakan Metode Kansei Enginering," TIN Universitas Tanjungpura, p. 1(3), 2017.

[4] I. S. \&. Suga, Dasar Perencanaan dan Pemilihan Elemen Mesin, 1991.

[5] M. I. Adikuncoro, "Perancangan Mesin Pencacah Plastik Portabe dengan Memanfaatkan Limbah Pegas Daus Kendaraan Sebagai Material Pisau Potong," Politeknik Negeri Bandung, Bandung, 2020. 